\title{
Tax Incentives and the Flow of Foreign Direct Investment to Non-Oil Sector: Empirical
}

\begin{tabular}{l}
\hline Joseph Amuka ${ }^{1}$ (iD) \\
Fidelis Ezeudeka ${ }^{2}$ (D) \\
\hline${ }^{1}$ University of Nigeria Nsukka Nigeria \\
${ }^{2}$ Federal Inland Revenue Service Abuja-Nigeria \\
(\$Corresponding Author)
\end{tabular}

\begin{abstract}
Foreign Direct Investment has become an important source of bridging the gap between domestic savings and domestic investments in developing countries in the past three decades. In order to increase the flow of foreign direct investment, Nigeria like many other developing countries reformed her tax system in late 1990s to create incentives for the flow of foreign direct investment into the country. She reviewed company income tax downward from $50 \%$ in 1980 s to $30 \%$ in 1999 . Similarly, investment allowance was reviewed upward from $25 \%$ in 1980 s to $95 \%$ in 1999 . This study investigated whether the incentive policy has brought any significant change in the pattern of flow of foreign direct investment to the non-oil sector. The study adopted a multiple regression model which was transformed into log-log model in the analysis. Regime switch model helped us to evaluate the effectiveness of the policy introduced in late 1999. Both company income tax and investment allowance appeared with the right sign. Result suggests that the tax incentive policy introduced changed the flow of foreign investment to the non-oil sector, showing that the country's tax incentives can help revive the ailing non-oil sector.
\end{abstract}

Keywords: Tax incentives, Foreign direct investment, Non-oil sector.

\section{Contents}

1. Introduction

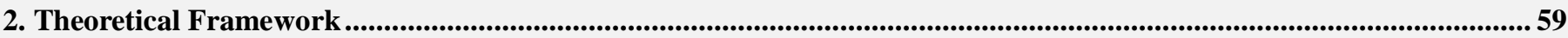

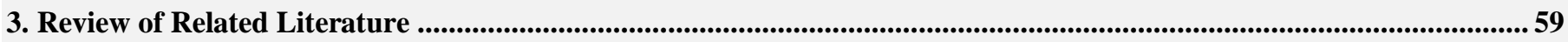

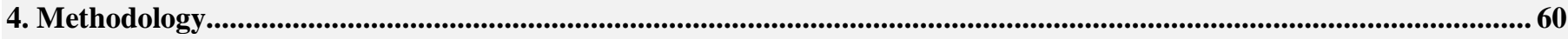

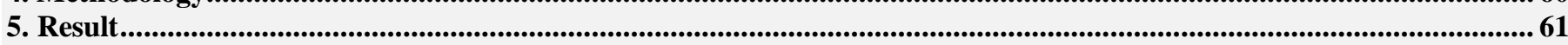

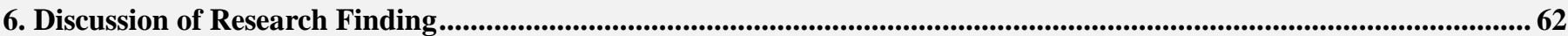

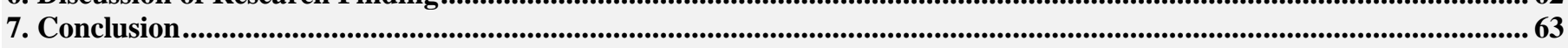

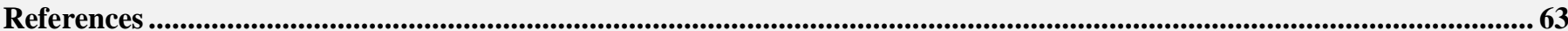

Citation | Joseph Amuka1; Fidelis Ezeudeka (2017). Tax Incentives and the Flow of Foreign Direct Investment to Non-Oil Sector: Empirical. Asian Journal of Social Sciences and Management Studies, 4(1): 57-64.

DOI:

$\operatorname{ISSN}(\mathbf{E})$ :

ISSN(P) :

10.20448/journal.500/2017.4.1/500.1.57.64 crossref

$2518-0096$

Licensed: $\quad$ This work is licensed under a Creative Commons Attribution 3.0 License (cc) E

Contribution/Acknowledgement: All authors contributed to the conception and design of the study.

Funding: $\quad$ This study received no specific financial support.

Competing Interests: The authors declare that they have no conflict of interests. Transparency:
vital features of the study have been omitted; and that any discrepancies from the study as planned have been explained.

History:

Ethical:

Publisher: Received: 26 July 2016/ Revised: 9 January 2017/ Accepted: 16 January 2017/ Published: 23 January 2017 This study follows all ethical practices during writing.

Asian Online Journal Publishing Group 


\section{Introduction}

The use of tax incentives as potent tools to induce flow of foreign direct investment into an economy increased in tempo since early 1990s in majority of the developing countries. The competition for foreign direct investment became so stiff that some of incentives designed were seen to be against the interest of the economies of the developing countries. Even at highpoint criticism, many of the developing countries remained indifference. There are scholars who gave their backing to the incentive policy and at the same time, some remained skeptical on how the incentives can bring good result. Kransdorff (2010); Christiansen et al. (2003) and Asiedu (2002) saw rationality in developing countries trying to induce inflow of foreign capital into their economy.

Asiedu (2002) says that foreign investment is a growth accelerator because it is a veritable source of investment capital, employment, managerial skills and technology. This she says is important in developing countries where savings mobilization is poor. Christiansen et al. (2003) share Asiedu's view and contend that in a depressed poor economy, foreign direct investment not only provide finance for long term investment, but can equally produce a spillover effects to other firms in the form of transfer of technology and human capital formation. Kransdorff (2010) also accepts that foreign direct investment goes with new technology and management practices which can benefit the economy of developing countries.

However, some other scholars saw cost in tax incentives which may work against the interest of developing countries at a later period (James, 2009; Klemm and Van, 2010). These scholars believe that tax incentives come with revenue loss to government which will have serious consequence on the spending power of the government in developing countries, especially in social services that affects the poor. In a similar manner, Edmiston et al. (2003) hold the view that tax incentives can increase the tax burden of those firms that are not benefiting from the given incentives. The consequence is that the increase in tax burden on non-benefiting firms can discourage them from further investment in that economy, even when they could have done so in the absence of those incentives. In that sense, tax incentives can crowd-out some other investments.

Nigeria turned attention to foreign sourcing of investment capital for two important reasons. First is the poor level of domestic savings which have been inadequate for the mobilization of long term investment capital needed to speed-up economic growth and development. The second major reason is the fall in international price of oil in early 1980 s which adversely affected the revenue profile of the government, causing serious slowdown in economic activities in the country. The sudden fall in global oil demand and price dealt a serious blow to Nigeria economy because of the large share of oil revenue in the total revenue of the government since early 1970s. With much revenue coming from oil, government over relied on oil as her major source of external revenue. Thus, government activities were almost grounded to a halt as soon as the revenue performance of oil fell. Resort to borrowing to finance government expenditure after the oil price fall plunged the country into serious internal and external crisis.

Nigeria's economic crisis lingered for long and effort by the government to remedy the situation led to the introduction of Structural Adjustment Programme (SAP) and economic liberalization in 1986. Structural adjustment and economic liberalization were intended to diversify the economy and reduce government dependent on the oil sector for her revenue. A decade after the introduction of structural adjustment and the liberalization of Nigerian economy, the expected improved performance of non-oil sector could not come to fruition. Trade and exchange rate liberalization failed to stimulate the growth of non-oil export revenue. The search for solution led to the introduction of tax incentives to induce flow of foreign capital into the country. Policy makers believed that inflow of foreign resources will raise the economy's carrying capacity which has been very low since the oil boom era

Nigeria investment promotion council was established in 1995 to negotiate major tax incentive packages to encourage, promote and coordinate inflow of foreign investment to the country, with particular attention to deserving industries and sectors. As a specific instruction, the commission was directed to identify the areas of great importance in the economy and recommend investment incentive measures consistent with the government policy. In response to this, the Nigeria Investment Commission went ahead to design some tax incentives in 1996 which will make the country one of the destinations of foreign direct investment not only in Africa but in the world. For the purpose of the growth of the non-oil sector, discriminatory tax incentives were introduced to favour investments in the manufacturing and agriculture businesses.

In the incentive reform, company income tax was reviewed downward to 30 percent from 50, and investment allowance reviewed upward to 95 percent from 25 for investments in non-oil activities. In the oil activities, new entrants into the sector are to pay profit tax of $50 \%$ for a period of 5 years, while the existing ones are to pay $65 \%$ of their earned profit as tax. Under the pioneer status, industries located at the economically disadvantaged areas are exempted from tax up to a maximum period of 7 years during which they are expected to recover their initial investment. In the oil sector, companies benefiting from pioneer status are only allowed maximum period of 5 years tax exemption. The incentive provisions are revelation of the interest of the government and her objective to revive the non-oil sector.

Foreign Direct Investment is the acquisition of not less than $10 \%$ shareholding of a firm by a foreign investor. It is the resources flowing into a country from outside for the purpose of building new plant, with non-citizens having at least $10 \%$ voting rights or voice in the management of the enterprise. Before the introduction of tax incentive in Nigeria in 1999, the share of the non-oil sector from the total foreign direct investment in Nigeria economy was 21.6 percent in 1984. The share fell ten years later to 11.2 percent in 1994. By 1996 when the tax incentives were being designed, the share of non-oil sector from the total flow of foreign direct investment was 2.64 percent. A year after the implementation of the incentive stimulus, which is, in 2000 , the share of non-oil from the total foreign direct investment to Nigeria rose to 10.5 percent, but declined to 5.4 percent in 2002, and rose again to 8.1 and 9.9 percent respectively in 2004 and 2007 (Central Bank of Nigeria Statistical Bulletin, 1995;2001;2007). The trend shows that the share of the non-oil sector from the total foreign direct investment flow to Nigeria between 1994 and 2007 has continued to fluctuate. This is what raised the concern in the minds of people on whether the incentives are really on track. 
Adepeju (2012) investigated how the tax incentives introduced in Nigeria have affected the flow of foreign direct investment into the oil sector of the Nigeria economy. His study shows that tax incentive has positive effect on the flow of foreign direct investment to the oil sector. In a similar manner, Saidu (2015) carried out a study on the effect of corporate taxation on foreign direct investment in Nigeria. His result shows that higher corporate tax will reduce the flow of foreign direct investment into Nigeria. The present study is however different from the two studies both in content and methodology. In content in the sense that the present study is directed to the non-oil sector in line with government major objective of introducing those incentives. Methodology in the sense that none of the studies evaluated the effect of the tax policy changes on foreign direct investment as expected in a research like this.

\section{Theoretical Framework}

Before the twenty-first century, the decision to invest outside the domestic economy was explained notably on the bases of differences in return to capital in different economies (capital theory), trade protection (Mundell and the Heckscher-Ohlin Model), level of risk attached to investment (Portfolio theory), and changes in factor intensity caused by technological innovation and knowledge diffusion (Product Cycle theory). The capital theory argues that investors are driven at any point in time by profit motives. Being money makers, investors are always looking for investment opportunities where the return to investment is higher. As a consequence, an economy will be a destination point for the flow of foreign resources if it offers higher return to capital when compared with other economies competing for the same scarce resources.

Trade protection theory hints that protective policy of countries is a strong factor which has influenced the flow of foreign direct investment because relocation is a means of indigenizing production. In this regard, firms try to take their investment to the countries where import trade is more restricted. However, for the Portfolio theory, investment and risk go together and the argument of the portfolio theory is that the level of risk a firm may encounter oversea determines whether it is worthwhile to invest in a particular country. As risk averse, a rational investor whether as an individual or corporate entity will go beyond the calculation of rate of return on investment to the calculation of risk that follow such return. In that case, a firm may not likely invest in the economy with high return to investment if the risk on investment is equally high. .

Because of the various criticisms which followed the theories discussed above, twenty-first century scholars have found the Eclectic Theory developed by Dunning a better guide in what may be the determinants of foreign direct investment. According to the Eclectic theory, three important factors drive firms to seek for oversea investment. They are (1) ownership, (2) location, and (3) internalization, all together known as the OLI model or Paradigm. Dunning's argument is that without any of the above advantages, a firm will rather remain in its home country than relocate its investment to another country.

Ownership advantage may come in the form of market size of the host country and the zeal to grow will push a firm to take its investment to where the market is large. More importantly, if the firm is in a monopolistic competitive market in its home country, movement to a new country is faster if it will find itself in a pure monopoly condition in another country. The other advantage which may compel a firm to invest in another country is the resource endowment possessed by the foreign country which the firm can use to lower its cost of production, especially when resources are less mobile. Finally, by internalization, the firm can be more efficient by relocating to another country because of its ability to make good use of some market imperfection and market failure to its advantage.

Despite the growing popularity of the Eclectic theory today, the capital theory is still relevant in the decision of firms to seek for oversea investment. This is because no matter what happens, the main objective of the business firm is to make profit. Tax incentive falls within the framework of capital theory because it affects the rate of return on investment. Higher tax rate reduces the net income of the firm and firm will likely invest in the environment with friendly tax policy. Favourable tax policy will have positive effect on the flow of foreign direct investment into a country. This underscores the recent aggressive use of tax incentives to drive foreign investment by majority of the developing countries.

\section{Review of Related Literature}

Foreign Direct Investment has been defined in different ways by scholars of international economics. Pettinger (2012) sees foreign direct investment as a movement of capital from one country (known as origin) to another country (known as host) which is meant to acquire physical capital such as factories or machines. The acquisition must be a lasting interest which involves control of at least $10 \%$ share or vote of an enterprise doing business outside the investor's home country. Mwilima (2003) clearly states that for a foreign investment to be defined as direct, an individual or entity must make a lasting interest in the management of an enterprise doing business in a foreign country which must include having at least $10 \%$ voting stock and equity share in that enterprise.

Organisation for Economic CO-operation and Development (OECD) (2008) in the same way sees foreign direct investment as an investment interest made by a citizen of a country in another country which gives him $10 \%$ voting right in an enterprise doing business in a country other than his own. Denisia (2010) equally saw foreign direct investment as not less than $10 \%$ holding of a firm's equity by an individual outside his home country. In all the above definitions, one will deduce that foreign direct investment entails a non-national purchasing a new capital in a firm outside his home economy. At least, the investor must have $10 \%$ shareholding or voting right in the firm.

Although research evidence on the effect of tax incentive on the inflow of foreign direct investment is scanty in Nigeria and some other Sub-Saharan Africa, such evidence abounds in Europe, America and Asia. What has remained clear from available studies is that results are never the same across countries. Countries encounter different results in the use of tax incentives to increase inflow of foreign direct investment into their economies. For instance, cross-country study done by Klemm and Van (2010) suggests that tax incentives have significant effect on the flow of foreign direct investments in Latin America and the Caribbean. For Africa, their study suggests that tax incentives have not been effective in this regard. The effect of tax incentives on foreign direct investment in Africa is 
similar to the research finding in post-communist countries by Beyer (2002). The study by Beyer (2002) reveals that tax incentives have not stimulated the inflow of foreign direct investment into the Post-Communist countries as expected.

Other research evidences that showed the potency of tax incentive to induce the flow of foreign direct investments include Buettner and Ruf (2005); Tung and Cho (2000); Guo (2010) and Shah and Slemrod (1990). Research evidences from these people showed that tax incentives increased the flow of foreign direct investments in Germany, China and Mexico. In all these studies, evidence suggests that tax incentives are important tools to use in inducing the flow of foreign resources or to increase re-investment in the host country by existing firms. Result of the other study in China by Lin and Wang (2014) was mixed. In the first instance industry specific tax incentive was attractive to Taiwanese enterprises. Unfortunate, the China's tax law as a whole did not provide incentive for location advantage for Taiwanese enterprises. Hence, there was a conflicting result in China between the studies of Lin and Wang (2014) and Guo (2010) which showed that foreign direct investment location increases in the country as corporate income tax as a whole and local tax rates fall.

But of note are some other studies which showed that tax incentives have not led to increase in the flow of foreign direct investment in some countries. Cross country study in 25 European Union by Wolf (2007) shows that corporate tax rate has an insignificant effect on the flow of foreign direct investment in the 25 countries studied. Though, the European countries are all in the developed countries category and the opportunities for growth are higher for firms in developing countries. The markets in developed countries are nearing saturation and completion is stiffer in them. The stiff competition may scare new firms even in the presence of incentives.

Effiok et al. (2013) carried out a research to investigate the effect of tax policy and incentives on foreign direct investment in the export processing zone in Nigeria. Their study has serious methodological problem because of the combination of primary and secondary data together. The use of macro data in a micro study is always unwarranted because of the misleading result it will produce. They used simple regression as if to say tax is the only determining variable that affects the flow of foreign direct investment. The present study used macro data in a macro study together with regime switch model to overcome the methodological problems in the study.

\section{Methodology}

The paper adopted a linear multiple regression model which was transformed into log-log model. The ordinary least squares econometric analysis was found to be a very appropriate tool for the analysis because of its unique properties. Regime switch model was used to take care of the tax policy change in Nigeria in 1999. The introduction of regime switch model is to measure the impact of tax policy change on the flow of foreign direct investment into Nigeria. The regime switch model is the appropriate way to measure the effectiveness of a regime change. Data were generated from (CBNSB, 1995;2001;2007;2014). The multiple regression models are specified as-:

$F d i_{t}=b_{0}+b_{1} \Sigma P n n_{t-i}+b_{2} \Sigma P C a p_{t-i}+b_{3} \Sigma E x_{t-i}+b_{4} \Sigma I n f_{t-i}+b_{5} \Sigma C i t_{t-i}+b_{6} \Sigma I v a_{t-i}+b_{7} \Sigma H u_{t-i}+E_{t} \ldots .1$

Transforming Equation 1 into log-log model in order to rescale and interpret the result in elasticities;

$\operatorname{lnFdi} i_{t}=b_{0}+b_{1}$ LnPnn $_{t}+b_{2}$ LnPCap $_{t}+b_{3} \operatorname{LnEx}_{t}+b_{4} \operatorname{Inf}_{t}+b_{5}$ Cit $_{t}+b_{6}$ Iva $_{t}+b_{7} L n H u_{t}+E_{t} \ldots \ldots \ldots .2$

Equation 2 explains foreign direct investment (Fdi) to the non-oil sector as being determined by the degree of openness (Pnn) defined as the ratio of the sum of export and import to GDP, per capita income (Pcap) which measures market size, exchange rate (Ex) and inflation (inf) which are the measure of macroeconomic stability, company income tax (Cit) and investment allowance (Iva) being the two tax incentives, and human capital (Hu).

$\ln =$ elasticity, $b_{0}=$ intercept and $b_{1}, b_{2}, \ldots, b_{7}=$ slope

\subsection{Cointegration and Error Correction}

Time series data have high probability of not being stationary and it is important to test their level of stationarity to avoid spurious results. Equation 2 was transformed into an Error Correction Model (ECM).

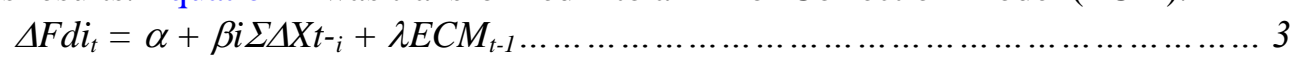

Where

$\Delta \mathrm{Fdi}_{\mathrm{t}}=$ differenced foreign direct investment

$\Delta \mathrm{X}_{\mathrm{i}=}$ differenced exogenous variables in the model

$\beta_{i}=\beta_{1}, \beta_{2}, \beta_{3}, \beta_{4}, \beta_{5}, \beta_{6}$ (slopes of the model that measures the long run relationship between foreign direct investment and the exogenous variables

$\lambda=$ parameter of the ECM and measures the adjustment to previous period equilibria achieved in the current period.

\subsection{Tax Policy Change}

The importance of the study is to find out if the tax incentive policy introduced in 1999 has produced any significant effect on the flow of foreign direct investment to the non-oil sector of Nigeria economy. Two methods can be used to make the evaluation in econometric analysis. They are the Chow test and the Dummy Variable estimation. Current research has shifted from chow test to Dummy variable estimation. The present study used the Dummy variable approach to evaluate the effect of tax policy change on inflow of foreign direct investment. Therefore, -

$\operatorname{LnFdi}_{t}=a_{0}+a_{1}$ Lnpnn $_{t-i}+a_{2}$ Lnpcap $_{t-i}+a_{3} \operatorname{Ex}_{t-i}+a_{4} \operatorname{Inf}_{t-i}+a_{5} \operatorname{LnHu}_{t-i}+U_{t} \ldots \ldots \ldots \ldots \ldots . .4$

Equation 4 cannot sufficiently measure stability or the significance of the tax policy change in 1999 on inflow of foreign direct investment to the non-oil sector. Hence,

$$
\operatorname{lnFdit}=\lambda_{0}+\lambda_{1} \ln P n n_{t}+\lambda_{2} \ln \text { Pcap }_{t}+\lambda_{3} \ln E x_{t}+\lambda_{4} \operatorname{Inf} f_{t}+\lambda_{5} \ln H u+\lambda_{6} D+\varepsilon_{t} \ldots \ldots \ldots \ldots \ldots \ldots \ldots \ldots \ldots
$$

Where

$\mathrm{D}=$ Dummy binary response variable for tax policy change (takes value 1 when there is change in policy and 0 otherwise)

$\mathrm{a}_{1}-\mathrm{a}_{5}, \lambda_{1}-\lambda_{6}=$ slope 
other variables remain as defined before.

From Equations 4 and 5, the value of incremental ' $F$ ' was computed for the significance of change in policy.

\section{Result}

\subsection{Unit Root Tests}

The first task in time series analysis is to test for stationarity of the data to avoid getting spurious result from the analysis. To ensure that the parameters are estimated using stationary time series data, the Augmented Dickey-Fuller (ADF) test for unit root was employed. The essence of the ADF tests is to verify the null hypothesis of unit root or non-stationary stochastic process. The result of the unit root test is presented in Table 1 below.

\subsection{Unit Root Test}

Table-1. The Summary Results of Unit Root Test

\begin{tabular}{|c|c|c|c|c|c|c|}
\hline \multicolumn{3}{|c|}{$\begin{array}{r}\text { Level } \\
\end{array}$} & \multicolumn{3}{|l|}{ First Difference } & \multirow[b]{2}{*}{$\begin{array}{l}\text { Order of } \\
\text { integration }\end{array}$} \\
\hline Variables & ADF test Statistics & $\begin{array}{l}1 \% \text { critical } \\
\text { Level }\end{array}$ & ADF test Statistics & $\begin{array}{l}1 \% \text { critical } \\
\text { Level }\end{array}$ & Prob & \\
\hline d.log_fdi & -1.718 & -3.485 & $-13.170 * *$ & 3.485 & 0.0000 & $1(1)$ \\
\hline d.log_pnn & 0.306 & -3.485 & $-13.395 * *$ & -3.485 & 0.0000 & $1(1)$ \\
\hline d.log_pcap & -2.767 & -3.485 & $-13.525 * *$ & -3.485 & 0.0000 & $1(1)$ \\
\hline d.ex & 0.201 & -3.485 & $-13.410 * *$ & -3.485 & 0.0000 & $1(1)$ \\
\hline d.inf & 3.058 & -3.485 & $-14.115 * *$ & -3.485 & 0.0000 & $1(1)$ \\
\hline d.cit & -1.067 & -3.485 & $-13.347 * *$ & -3.485 & 0.0000 & $1(1)$ \\
\hline d.iva & -0.761 & -3.485 & $-13.181 * *$ & -3.485 & 0.0000 & $1(1)$ \\
\hline d.log_hu & -2.912 & -3.485 & $-13.511 * *$ & -3.485 & 0.0000 & $1(1)$ \\
\hline
\end{tabular}

Source: author's computation based on from Central Bank of Nigeria

Note: $* *$ indicate significance at $1 \%$.

From the result in Table1 above, the ADF indicates that all the variables are integrated at order one $(\Delta=1)$. This is an indication of possible long-run linear combination of the variables, hence, the study conducted a cointegration test for possible long run relationship among the dependent and independent variables.

\subsection{Cointegration Test}

Table-2. Summary Results of the ADF Cointegration Test

\begin{tabular}{l|l|l|l|c}
\hline & Test Statistic & $\mathbf{1 \%}$ Critical Value & $\mathbf{5 \%}$ Critical Value & $\mathbf{1 0 \%}$ Critical Value \\
\hline $\mathrm{Z}(\mathrm{t})$ & -1.058 & -3.485 & -2.885 & -2.575 \\
\hline
\end{tabular}

From the ADF cointegration test conducted, the absolute value of the computed ADF test Statistic (-1.058) is less than the absolute value of the tabulated ADF Critical Value (-2.885) at 5\% level of significance as presented in Table 2 above, hence, making all the variables not to have long run relationship, that is, they are not cointegrated. Because the dependent and independent variables are not cointegrated, we could not proceed to error correction model as specified in Equation 3.

\subsection{Regression Result}

Result of the regression is presented in Table 3 below.

Table-3. Dependent variable $=$ d.log_fdi

\begin{tabular}{|c|c|c|c|c|}
\hline Variables & Coef. & Std. Err. & $\mathbf{t}$ & $\mathbf{P}>|\mathbf{t}|$ \\
\hline d.log_pnn. & 0.343721 & 0.1411218 & $2.44 * * *$ & 0.016 \\
\hline d.log_pcap & 0.0075598 & 0.2525796 & 0.03 & 0.976 \\
\hline d.ex & -0.0232011 & 0.0045487 & $-5.10 * * *$ & 0.000 \\
\hline d.inf & -0.0129584 & 0.0040164 & $-3.23 * * *$ & 0.002 \\
\hline d.cit & -0.1211886 & 0.0533941 & $-2.27 * *$ & 0.025 \\
\hline d.iva. & 0.0109855 & 0.0057815 & $1.90 *$ & 0.059 \\
\hline d.log_hu. & 0.1985137 & 0.4662362 & 0.43 & 0.671 \\
\hline _cons & 0.0198207 & 0.0286198 & 0.69 & 0.490 \\
\hline
\end{tabular}

Source: author's computation based on regression result

$* * *=$ significant at $1 \% ; * *=$ significant at $5 \% ; *=$ significant at $10 \%$;

$\mathrm{R}^{2}=0.27$

$\operatorname{DW}(8,175)=2.006$

From the result presented in Table 3, all the variables in the model appeared with the expected signs. It is not only the core variables that satisfied the a priori theoretical expectation but other determining variables as well. Openness (pnn), per capita income (pcap), investment allowance (iva) and human capital (hu) have positive relationship with foreign direct investment to the non-oil sector. But inflation (inf), exchange rate (ex) and company income tax (cit) negatively affect flow of foreign direct investment to the non-oil sector in Nigeria within the period of study.

Before we proceeded to the discussion of research finding, some post estimation tests were carried out to find out the reliability of the result presented in Table 3. The tests are important to check the violation of the assumptions of the ordinary least square. 


\subsection{Test for Multicollinearity}

Existence of collinearity in a regression result violates one of the assumptions of ordinary least square and makes the result unacceptable for policy reference. The result of Multicollinearity conducted is presented in Table 4.

Table-4. Summary Results of the Multicollinearity Test

\begin{tabular}{l|c|l}
\hline \multicolumn{1}{c|}{ Variable } & VIF & 1/VIF \\
\hline cit & 1.64 & 0.609452 \\
\hline iva & 1.47 & 0.681556 \\
\hline log_pnn & $1 . .30$ & 0.68405 \\
\hline log_pcap & 1.33 & 0.752046 \\
\hline inf & 1.13 & 0.883143 \\
\hline log_hu & 1.14 & 0.875758 \\
\hline ex & 1.02 & 0.975740 \\
\hline \multicolumn{1}{c}{ Mean VIF } & 1.29 & \\
\hline
\end{tabular}

Source: author computation based on from Central Bank of Nigeria

Result of the multicollinearity test is presented in Table 4. Since the inverse of the variance inflation factor (1/VIF) is closer to the value 1 , there is no suspicion of multicollinearity.

\subsection{Specification Error Test}

The Ramsey Reset test was employed to test for wrong specification in the model. Ramsey Reset test followed the F-distribution. The result is presented below.

Hence,

$\mathrm{F}_{\mathrm{tab}(0.05}(3,164)=2.60$

$\mathrm{F}_{\text {cal }}(3,164)=1.58$.

The result therefore suggests that the model is well-specified since $\mathrm{F}_{- \text {cal }}<\mathrm{F}_{-0.05}$, and the null hypothesis is rejected and the conclusion is that the model is well-specified.

\section{Discussion of Research Finding}

All the tests conducted have not shown any violation of the assumptions of the ordinary least square which can impose serious limitation in accepting the regression result presented in Table 3 above. Our detailed discussion was restricted to the tax incentives, the interest of the study.

\subsection{Tax Incentives}

The variables used to evaluate the tax incentives in Nigeria are company income tax (cit) and investment allowance (iva). Company income tax has a negative coefficient according to result in Table 3 , revealing negative relationship between company income tax and flow of foreign direct investment to the non-oil sector of Nigeria. The consequence of the negative relationship is that as company income tax fall the flow of foreign direct investment to the non-oil sector increases. Higher company income tax will lead to reduction in the amount of foreign direct investment flowing into the non-oil sector of the country. The two move in the opposite direction.

From Table 3,1\% increase in company income tax will lead to $0.12 \%$ fall in the flow of foreign direct investment to the non-oil sector of the economy. On the other hand, a reduction in company income tax by $1 \%$ will increase the flow of foreign direct investment by $0.12 \%$. Based on the probability, company income tax has a significant effect on the movement of foreign direct investment into Nigeria within the period the study covered. The significant effect of the tool on the flow of foreign resources justifies the revenue sacrificed by the government for the moment. Government expects to recover the revenue lost at the initial period of incentive when business activities pick up in future.

Our attention turns to investment allowance and its effect on the flow of foreign capital in the non-oil sector of Nigeria. The positive coefficient of the variable signifies that it satisfied the a priori theoretical expectation. It is a sign that investment allowance and foreign direct investment into the non-oil sector move in the same direction. When investment allowance increases, more firms will invest in the non-oil sector. If government increases investment allowance by 1 percent, foreign direct investment will increase by 0.01 percent, and 1 percent fall in investment allowance will reduce flow of foreign investment by 0.01 percent. However, investment allowance has no significant effect at the $5 \%$ level on the flow of foreign direct investment into Nigeria within the period of study.

The outcome of this study is very important to Nigeria and some other developing countries that have employed different tax incentives to mobilize foreign capital and complement domestic savings. Nigeria introduced different tax incentives in 1999 as a strategy to mobilize more investment in the non-oil activities. Mobilization of foreign resources became very important because of poor domestic savings which has affected domestic investment in the real sectors, and has slowed down economic growth and development. Nigeria had depended on revenue from oil to finance government expenditures before the move. The performance of the non-oil as sector as well as its contribution to the revenue of the government in Nigeria fell drastically after the oil boom in early 1970s.

Since early 1980s, Nigerian government has been trying to find solution to the revival of the non-oil sector so that the sector plays its role of growth driver. The effort of government to revive and diversify the economy was frustrated against the backdrop of the weakness of the economy to support long term investment. As an alternative to domestic mobilization of investment funds, the country offered fiscal incentives to foreign investors in varying degrees. The cost of doing business in the country was reduced through tax reduction so that higher profit will be an inducement to locate investment in the economy.

By reducing company income tax, government is indirectly reducing her tax income. By implication, her spending power is negatively affected. However, it is expected that with the reduction in company income tax, the cost of doing business in Nigeria will fall. This will send positive signal to firms to come to the country and invest. When investment capital flow from outside into the economy, economic activities will come to live in the sectors 
affected. With increase in economic activities, the demands for factors of production will equally increase and invariable raise factor income and government revenue from income tax. Therefore, government revenue may fall in the short-run, in the long-run, the revenue lost will be recovered.

This research finding has suggested that the expectation of the Nigerian government when she introduced the fiscal incentives may be met. At least, the effect of company income tax has shown that. But for the investment allowance, the result suggests that government should think twice. There are two good reasons she should do so. In the first place, it has no significant effect at the $5 \%$ level on the flow of foreign capital to the deserved sector. In the second place, the firms are repatriating home almost all the profits earned in Nigeria economy. It is never done like that in other countries because it denies an economy of substantial amount of investible fund. Even if the country will offer incentive through investment allowance, it should not be as high as 95\%. This is another form of capital flight.

\subsection{Tax Policy Change}

The result presented in Table 3 only explained the effect of tax incentives on the flow of foreign direct investment to the non-oil sector of Nigeria economy. It is not an evaluation of the effectiveness of the change in tax policy to bring an increase in inflow of foreign direct investment to the non-oil sector. In order to evaluate the effectiveness of the tax incentive policy change on inflow of foreign direct investment to the non-oil sector, incremental ' $F$ ' based on regime switch model of Equations (4) and (5) was estimated. The result of the effect of tax incentive policy change on the flow of foreign direct investment to the non-oil sector of the Nigeria economy is presented in Table 5 below.

Table-5. Summary Results of the Incremental "F"

\begin{tabular}{|c|c|c|c|c|c|}
\hline & \multicolumn{5}{|c|}{ Block Residual } \\
\hline Block & $\mathbf{F}$ & df & df & $\operatorname{Pr}>\mathbf{F}$ & $\mathbf{R 2}$ \\
\hline $\mathrm{d} 1$ & 132.14 & 1 & 174 & 0.0000 & 0.4316 \\
\hline
\end{tabular}

The important thing to note in estimating the effect of regime change on the dependent variable is that the coefficients of the independent variables no longer matter. It is the value of the incremental ' $F$ ' that is important for policy purpose. From, Equation (5), the incremental F-test was estimated to determine whether tax policy change significantly affects foreign direct investment (Fdi) inflows to Nigeria economy.

\subsection{Evaluation of Change in Tax Policy}

From the result in Table 5, the value of incremental F- is highly significant at $1 \%$ with a probability of 0.000 . This therefore suggests that tax policy change significantly affect foreign direct investment (fdi) inflow into the Nigerian economy. Flow of foreign direct investment to the non-oil sector changed with the introduction of tax incentives in Nigeria in 1999. To say the least, the pattern of foreign direct investment to the non-oil sector changed due to the introduction of tax incentives.

From the point of view of policy shift, the objective of the introduction of the policy is being achieved for now. Thus, if the incentives continue, every other thing remaining the same, the flow of foreign direct investment to the non-oil sector will revive the sector and position it as the growth driver of the economy. The message it is sending to government is that Nigeria is reaping the gain from the introduction of tax incentives in late 1990s.

\section{Conclusion}

The competition to mobilize capital funds from outside the domestic economy increased so much in the last three decades, especially among developing countries who are more hit by poor domestic savings. Both theory and empirical evidence have provided different sides of tax incentives and how they have affected the flow of foreign direct investment in many countries. In Nigeria, tax incentive policy was implemented in the late 1990s. Hence, the country is not among the early implementers of fiscal incentives. In the study by Nwankwo (2006) she discovered that natural resources and political instability were the major attractors of foreign direct investment into Nigeria. Bazo (2008) equally hinted that developing countries will find it difficult to mobilize foreign direct investment in the presence of political instability. But, today, there is an evidence to suggest that incentive factors can drive the flow of foreign direct investment into a developing country like Nigeria.

Finally, the study was undertaken for the purpose of finding out if tax incentives can help revive the ailing nonoil sector through mobilization of foreign capital. The conclusion is yes, it can, based on evidence. This is because the pattern of flow of foreign capital to Nigeria changed after the introduction of tax incentives with the non-oil sector benefiting from it. Though it is arguable to say that there are costs associated with incentives such as revenue loss, the gain is also there.

\section{References}

Adepeju, B.S., 2012. The impact of tax incentives on foreign direct investment in the oil and gas sector in Nigeria. Journal of Business and Management, 6(1): 1-15. View at Google Scholar $\mid$ View at Publisher

Asiedu, E., 2002. On the determinants of foreign direct investment to developing countries: Is Africa different? World Development, 30(1): 107-119. View at Google Scholar $\mid$ View at Publisher

Bazo, P.A., 2008. Do developing countries' tax incentives attract investment or create disaster? Tax Notes International, 52(4): 299-303.

Beyer, J., 2002. Please invest in our country-how successful were tax incentives for foreign investment in transition countries? Communist and Post-Communist Studies, 35(2): 191-211. View at Google Scholar | View at Publisher

Buettner, T. and M. Ruf, 2005. Tax Incentives and the location of FDI: Evidence from A Panel of German Multinationals. Retrieved from www.bundesbank.de.

Central Bank of Nigeria Statistical Bulletin, 1995. Annual Statistical Bulletin, 6.

CBNSB, 2001. Annual Statistical Bulletin, 12.

CBNSB, 2007. Annual Statistical Bulletin, 18. 
CBNSB, 2014. Annual Statistical Bulletin, 25.

Christiansen, H., C. Oman and A. Chariton, 2003. Incntives -based competition for foreign direct investment: The case of Brazil. OECD Working Papers on International Investment 2003/01.

Denisia, V., 2010. Foreign direct investment theories: An overview of the main FDI theories. European Journal of Interdisciplinary Studies, 2(2): 104-110. View at Google Scholar

Edmiston, K.D., S. Mudd and N.T. Valev, 2003. Incentive targeting, influence peddling and foreign direct investment.

Effiok, S.O., A.T. Tapang and O.E. Eton, 2013. The impact of tax policy and incentives on foreign direct investment (FDI) and economic growth: Evidence from export processing zone (EPZ) in Nigeria. European Journal of Commerce and Management Research, 2(9): 101-196. Guo, J., 2010. The effect of tax rates on foreign direct investment in China. Journal of International Management Studies, 5(1): 31-37. View at
Google Scholar

James, S., 2009. Incentives and investments: Evidence and policy implications. Advisory Services, World Bank.

Klemm, A. and P.S. Van, 2010. Empirical evidence on the effects of tax incentives, Universiteit gent, Faculteit economie. EN BedrijFskunde. Working Paper No. D/2010/7012/44.

Kransdorff, M., 2010. Tax incentives and foreign direct investment in South Africa. Consillience: Journal of Sustainable Development, 3(1): 68-84. View at Google Scholar

Lin, W. and J. Wang, 2014. Do the changes in tax incentives encourage direct investment in China by Taiwanese enterprises? Journal of Accounting and Taxation, 6(2): 38-53. View at Google Scholar $\mid$ View at Publisher

Mwilima, N., 2003. Foreign direct investment in Africa. Social observatory pilot project. Final Draft Report for the Labour Resource and Research Institute. pp: 29-45.

Nwankwo, A., 2006. The determinants of soreign direct investment in Nigeria. Paper Presented at Global Conference on Business and Economics, Gutman Conference Centre, USA, 15-17 October.

Organisation for Economic CO-operation and Development (OECD), 2008. Benchmark definition of foreign direct. 4th Edn.

Pettinger, T., 2012. Foreign direct investment, economics help. Retrieved from www.economicshelp.org.

Saidu, A.S., 2015. Corporate taxation and foreign direct Investment in Nigeria. European Journal of Accounting, Auditing and Finance Research, 3(8): 17-24. View at Google Scholar

Shah, A. and J. Slemrod, 1990. Tax sensitivity of foreign direct investment: An empirical assessment. World Bank Research Working Paper Series No.100.

Tung, S. and S. Cho, 2000. The impact of tax incentives on foreign direct investment in China. Journal of International Accounting, Auditing and Taxation, 9(2): 105-135. View at Google Scholar | View at Publisher

Wolf, G., 2007. Foreign direct investment in the enlarged EU: Do tax matter and to what extent? Open Economies Review, 18(3): 327-346. View at Google Scholar | View at Publisher 